\title{
6 Social Meaning and Variation in Perception: Beijingers' Attitudes Towards Beijing Mandarin
}

\author{
Hui Zhao
}

\section{Introduction}

The study of language variation and change aims to understand the social meaning of linguistic features both in production and in perception, but there is a lack of research on non-English and non-Western languages. This chapter examines the perception of variation in Beijing Mandarin, the (non-standard) vernacular variety in Beijing which shares many similarities with standard Chinese and explores the social meaning of this variety and its features in contemporary Chinese society. It also sheds light on how language variation of different linguistic features (phonetic, lexical and grammatical) is perceived in Beijing Mandarin and in general.

\section{Social meaning and variation}

Variationist sociolinguistics aims to understand how social meanings are constructed and contextualized. Often termed 'first-wave' (Eckert, 2012), earlier variationist research focused on meanings related to broad socioeconomic categories such as social class and sex (Labov, 1966; Trudgill, 1974; Wolfram, 1969). Sociolinguists during the 'second-wave' era, in comparison, combined meaning-making with community-specific practices in speech communities (Eckert, 1988; Milroy \& Milroy, 1978). More recently, 'third-wave' variationist scholars investigate meanings indexed by variation, conceptualized in the theory of indexicality developed by Silverstein (1976). Indexicality is the 'creation of semiotic links between linguistic forms and social meanings' (Bucholtz \& Hall, 2005) and links variation (in linguistic features, accents and/or language varieties) with contextual meanings in language use. These social meanings, 
according to Eckert (2008), seldom have simple one-to-one correlations with social categories or practices; rather, linguistic features often index a constellation of social meanings termed an 'indexical field'. For example, studies on the release of $/ \mathrm{t} /$ in American English have shown how indexicality helps to understand its various social meanings (that forms an indexical field) and how specific indexical meanings are conveyed in different communities (e.g. Benor, 2001; Bucholtz, 2001; Podesva et al., 2002).

Moreover, the same linguistic features can have different meanings across different communities and contexts, due to the indeterminate nature of the relationship between meanings and linguistic features (Podesva \& Chun, 2007), and speakers can navigate this indexical field in language production and perception depending on the context where the interaction occurs (see Campbell-Kibler, 2006; Eckert, 2012; Heinrich, this volume; Johnstone \& Kiesling, 2008; Moore \& Podesva, 2009; Villarreal, 2018; Walker et al., 2014a).

\section{Perceiving social meanings}

Existing literature on language perception and variation has linked variation in perception with various meanings related to, for example, geographic areas, accents, personal traits and gender and sexuality. In folk linguistics, the perception of regional accents helps linguists understand how listeners perceive differences in sounds as markers for geographical regions (Babcock, 2014; Benson, 2003). Using the matched-guise technique, Lambert and colleagues studied bilingual Canadians' attitudes towards English and French in terms of personal traits including education and attractiveness (Lambert et al., 1966). The meaning of -in/-ing variation in English has been studied extensively, showing that talkers are associated with different personal attributes (e.g. intelligence) depending on whether they use the -in or -ing variant (Campbell-Kibler, 2006, 2011; Tamminga, 2017). More recently, perceptions of gender and sexuality in language use have also been researched using digitally manipulated guises (Campbell-Kibler, 2011; Levon, 2006; Levon \& Fox, 2014; Pharao et al., 2014).

More research on the perception of language variation, especially in non-English and non-Western languages, is needed to fully understand how listeners engage in the process of meaning-making. Within the Chinese context, there are very few studies that make the association between variation, social meaning and perception, and existing perceptual works mainly investigate the use of standard language and dialects/ minority languages in China, Taiwan (Feifel, 1994; Lin, 1987) and Singapore (Chong \& Tan, 2013). Using the matched-guise technique, these studies have found that the standard variety enjoys high status in contrast with other Chinese dialects, including Shandong Mandarin 
dialect in Shandong province (Zhang, 1990), Guangdong province (Zhang et al., 2003) and Cantonese in Hong Kong (Lai, 2007). Different varieties are associated with different meanings on the solidarity dimension among Chinese speakers (Feifel, 1994; Lin et al., 2010; Zhang, 1990; Zhang et al., 2003). Some scholars link local varieties with positive affective qualities (Lin et al., 2010; Zhang et al., 2003), while others fail to find such clear correlations (Chong \& Tan, 2013; Zhang, 1990).

As can be seen, there is a lack of research on linguistic variation and social meaning in perception in China. By examining the perception of language variation in Beijing Mandarin and the social meaning of this local Mandarin dialect, this chapter seeks to help fill the gap in Chinese sociolinguistics, addressing the lack of research on linguistic variation and social meaning in perception in contemporary Chinese society.

\section{Background}

The focus of this chapter, Beijing Mandarin, also called Beijinghua (literally meaning 'Beijing speech'), is a Mandarin Chinese variety and is the local vernacular used in China's capital city of Beijing. Mandarin Chinese, also known as Beifanghua (literally translated as 'Northern speech'), is the mother tongue of more than $70 \%$ of the population in China (Li \& Thompson, 1981; Norman, 1988). There is no official estimate of the speaker population for Beijing Mandarin, though the capital city's 14 million non-migrant residents ${ }^{1}$ (out of 21.5 million residents) would mean it is reasonable to assume a sizeable speaker population (Beijing Municipal Bureau of Statistics (BMBS), 2020).

Existing research on the local dialect in Beijing is largely limited to (descriptive) dialectology where various aspects of the vernacular (e.g. phonology, syntax and lexicon) are documented (Hu, 1986a, 1986b, 1987; Lin, 2000; Xu, 1990; Zhou, 1998, 2002). Specific linguistic features considered stereotypical of the dialect have also received scholarly attention, though again from a descriptive perspective. To date, the only variationist studies of Beijing Mandan have been conducted by Zhang (2001, 2005, 2007, 2008), who examined the use of local and supralocal features in the construction of professional identities among business managers. Jing and Zhu's (2016) study on language attitudes among Beijing residents also explored the sociolinguistics of Beijing Mandarin, using more direct methods including telephone interviews and questionnaires.

The study presented here is part of a project on the social meaning of Beijing Mandarin in both production and perception (Zhao, 2018a). The chapter examines three linguistic features: (a frequent use of) neutral tone, classifier omission and intensifier te. The use of these features is associated with non-standard varieties of Mandarin, as they are considered nonstandard and/or ungrammatical in the standard language in China, often called Putonghua (literally translated as 'common speech') but also 
referred to as standard Chinese (see Feng, this volume; Luo, this volume, for details on Putonghua promotion in China; and see Wang, this volume, for another example of regional variation within Mandarin Chinese). I explain the details of these features in the following paragraphs.

Beijing Mandarin has four lexical tones in stressed syllables (represented by tone numbers): high-level (55), high rising (35), low fallingrising/dipping (214) and high pitch-falling (51) (Chao, 1968). When unstressed, a syllable loses its original tone and becomes 'neutralized'; its tone then varies depending on the tone of the surrounding words or morphemes and the syllable carries a 'neutral tone' instead (Chen \& Xu, 2006; Norman, 1988). Neutral tone can only occur in non-initial syllable positions and is often found in function words such as sentence-final particles. For example, /fən/ can mean 'fragrance', 'tomb', 'powder', 'element' when carrying a tone and is also used in words such as $/ \mathrm{fu}^{35} \mathrm{f}$ ən/ to mean 'fortune'. In comparison with Putonghua, Beijing Mandarin has a larger inventory of words with a tone that can be neutralized. $\mathrm{Lu}$ (1995) has suggested at least $20 \%$ of the words with a neutral tone in Beijing Mandarin are not neutralized in Putonghua, potentially resulting in Beijingers using more neutral tone than speakers of other varieties, including the standard variety.

To date, Jing (2002) and Zhou (2006) have investigated Beijing speakers' use of neutral tone: Jing used self-reported data from Beijing Mandarin speakers, while Zhou analyzed spontaneous speech from a corpus compiled in the 1980s. They found that neutral tone is preferred by male speakers and those with a lower education level/occupation status. Moreover, Q. Zhang's (2005) research on Beijing Mandarin also investigated neutral tone variation. Using speech data from Beijing professionals in international and state-owned businesses, she found that managers in foreign-owned companies ('yuppies') refrain from using neutral tone, in order to maintain their cosmopolitan identity.

Classifiers in Mandarin Chinese are a group of obligatory parts of speech that 'occur with a number, and/or a demonstrative or certain quantifiers' when preceding nouns in noun phrases, e.g. $y i$ (one) $+g e$ (classifier) + ren (person) (Li \& Thompson, 1981). In Beijing Mandarin, classifiers can be omitted in this structure, e.g. ' $y i$ (one) + ren (person)' (Tao, 2006). Classifier omission is unique to Beijing Mandarin and has barely been investigated before, although it is sometimes mentioned as a Beijing feature (Dong, 2004; Du, 1993; Huang, 2003; Liu, 2004) and its syntax was studied by Tao (2006) and Wu (2005).

The intensifier te (meaning 'very') is a lexical feature in Beijing Mandarin believed to be shortened from another intensifier, tebie. It has only started to gain popularity since the 1970s (Xu, 1990). Dialectology studies describe te as a northern feature used primarily in Beijing (Hao, 2012; Qi, 2012). Existing research is largely descriptive and focuses on written texts and dictionaries (Fu, 2014; Hao, 2012; Liu \& Cao, 2011). 


\section{Methods}

This study sought to elicit speakers' responses to the three linguistic features in perception, using the matched-guise technique. Specifics of the methods are provided below.

\section{Experiment design}

Two base sentences containing all three variables were designed to create the stimuli played to the listeners (Examples 1 and 2 below). The base sentences' topics were neutral: One referred to a city and the other to attending a conference, to avoid including positive or negative associations for the listeners, for example, relating to social status and birthplace as well as the formality of the utterances.

$\begin{array}{llllll}\text { gongsi } & \text { suozaide } & \text { chengshi } & \text { shengchan } & \text { xigua (gua1/gua0), suoyi } \\ \text { company } & \text { locate } & \text { town } & \text { rich-produce } & \text { watermelon } & \text { therefore } \\ \text { suiran } & \text { zhishi } & \text { yige }(y i) \text { xiao } & \text { chengshi, } & \text { que ben }(t e) & \text { youming } \\ \text { though } & \text { only } & \text { one-CL small town } & \text { but very } & \text { famous }\end{array}$

'The city where the company is located produces watermelons; therefore, it is quite famous despite being a small town'.

2 ta qu canjia yige(yi) buiyi, bei anpai zai

he go participate one-CL conference PREP arrange at

zaochen(chen2/chen0) diyige fayan, suoyi ben(te) jinzhang.

morning first speech therefore very nervous

'He is going to a conference and has been asked to be the first speaker in the morning, so he is very nervous'.

One male talker (aged 24) and one female talker (aged 20) were recruited to record these sentences (Sentence 1 and 2), which were later digitally altered to create the stimuli. Both speakers were native Beijing Mandarin speakers who had grown up in Beijing and were undergraduate students in TV broadcasting at a Beijing university, ensuring that they had received training on broadcasting in Putonghua. Four recordings (A, B, C and D) from each speaker (eight in total) were obtained, in which $\mathrm{A}$ and $\mathrm{B}$ contained the standard variants of all three variables and $\mathrm{C}$ and $\mathrm{D}$ contained all the local variants. Recordings $\mathrm{A}$ and $\mathrm{C}$ were based on the first sentence, and $\mathrm{B}$ and $\mathrm{D}$ on the second. For each talker, I then extracted all three variables from Recording A, B, C and D (12 extractions across two sentences) and replaced the respective variables in Recording $\mathrm{A}$ and $\mathrm{B}$, i.e. the standard versions, to create the experiment stimuli. To illustrate, I provide all eight possible combinations in each sentence for each talker in Table 6.1.

With two sentences, two speakers, and three binary variables, a full set of all the possible combinations yielded 32 stimuli. To minimize any influence of speech rate as noted by Street and Brady (1982) and Street 
Table 6.1 Combinations of three variables

\begin{tabular}{llll} 
Guise & Classifier omission & Neutral tone & Intensifier te \\
\hline 1 & - & - & - \\
\hline 2 & + & - & - \\
\hline 3 & - & + & - \\
\hline 4 & - & - & + \\
\hline 5 & + & + & - \\
\hline 6 & - & + & + \\
\hline 7 & + & - & +
\end{tabular}

et al. (1983), the lengths of stimuli based on Sentence 1 were controlled at $7.7 \pm 0.2 \mathrm{~s}$ and those based on Sentence 2, $6.9 \pm 0.2 \mathrm{~s}$. The stimuli were tested on native Mandarin speakers to ensure their naturalness prior to the experiment.

\section{Questions}

Listeners were asked 11 questions in the experiment after each sentence. Firstly, listeners were asked how likely it was that the speaker was talking with superiors at a meeting or with family/friends at dinner (Q1). They rated the talker on a 5-point scale with meeting and dinner as the two poles.

The traditional semantic differentiations where listeners rate the talkers on a scale between two extremes (e.g. good vs. bad) are often used in perception studies (Preston, 2011). I included them in the next set of questions to study potential social attributes assigned to Beijing Mandarin speakers (Q2.1-Q2.8). Four of the questions were designed to assess the perceived 'status' of the Beijing Mandarin features (education, intelligence, elegance and leadership), and the other four were to assess perceptions on the 'solidarity' dimension (warmth, loyalty, temper and sincerity). All ratings were presented on a 5 -point Likert scale.

In Q3, participants were asked to rate if the speaker sounded like a Beijinger, also on a scale from 1 to 5 . The last question (Q4), adopted from Labov (1972), asked listeners to choose a suitable occupation for the speaker from a list of pre-determined jobs including manager, office assistant, waiter/waitress and taxi driver. These jobs, which differ in prestige and social status, were used to see how people perceived Beijing Mandarin in terms of social status other than personal traits. A list of all 11 questions is provided in the appendix to this chapter. 
Table 6.2 Sets of guises used in randomization

\begin{tabular}{llll} 
Set & Speaker & Sentence & Number of guises \\
\hline Set A & Male & 1 & $2^{3}=8$ \\
\hline Set B & Male & 2 & $2^{3}=8$ \\
\hline Set C & Female & 1 & $2^{3}=8$ \\
\hline Set D & Female & 2 & $2^{3}=8$
\end{tabular}

\section{Procedure}

The experiment was conducted online using the Experigen platform (Becker \& Levine, 2014). In this project, I employed a $2(\mathrm{NT} /$ no-NT)*2 $(\mathrm{CL} /$ no-CL)*2 (INT/no-INT)*2 (Sex)*2 (Sentence) between-subject factorial design, in order to be able to investigate the response towards each of the three binary variables and the interactions between them (Abbuhl et al., 2014). However, with a total number of 32 guises, it was unrealistic for every participant to listen to all guises without either noticing there were only two speakers or what the target variables were. For this reason, the guises were fully randomized to allow each participant to listen to only four guises (one guise from each speaker with each sentence) so that the experiment would take about 15 minutes and the listeners never had to hear the same speaker and sentence combination twice.

During the experiment, a preview of the experiment page layout was first shown to the participants to familiarize them with the structure. Then, the experiment scripts randomly selected one out of the eight guises within each of the four sets (Table 6.2) and randomized the sequence of the four selected guises.

Participants therefore listened to four recordings and answered the same experiment questions immediately after each recording. A survey on general language use was presented after the last set of questions and allowed participants to fill in their answers and leave comments and their contact information. All experiment materials were presented to participants in Chinese.

\section{Results}

Fifty native Beijingers participated in the experiment. Of these, 40 were undergraduate students, and the remaining 10 were postgraduate students. They were all native Beijing Mandarin speakers and students in universities in Beijing in 2014. Overall, 28 female and 22 male listeners aged from 18 to 27 (mean age $=21.9$ ) were recruited. As each listened to and rated four stimuli (two each from the male and female talkers), 200 evaluations were collected. 
Table 6.3 Principal component analysis loadings (rotation: promax)

\begin{tabular}{lcc} 
& $\begin{array}{l}\text { Component 1 } \\
\text { Solidarity }\end{array}$ & $\begin{array}{l}\text { Component 2 } \\
\text { Status }\end{array}$ \\
\hline Warmth & 0.92 & -0.29 \\
\hline Loyalty & $\mathbf{0 . 7 1}$ & 0.00 \\
\hline Temper & 0.43 & 0.14 \\
\hline Sincerity & 0.73 & 0.16 \\
\hline Education & -0.21 & $\mathbf{0 . 9 4}$ \\
\hline Intelligence & 0.19 & 0.57 \\
\hline Elegance & 0.01 & $\mathbf{0 . 8 0}$ \\
\hline SS loadings & 2.08 & 1.89 \\
\hline Cumulative variance & 0.52 & 1.00
\end{tabular}

Note: Loadings greater than 0.33 are in bold.

The internal consistency of the eight questions on the status and solidarity dimensions was first checked using a Cronbach's $\alpha$ test in R (R Core Team, 2020) to determine whether they adequately measured the two dimensions. An acceptable score of 0.7 was achieved by removing Question 2.8 ('like a subordinate vs. like a leader'), and therefore, in the following analysis, results on the leadership question will not be discussed. For the remaining seven questions, a principal component analysis was conducted to reduce the number of factors used in later regressions, and all components with eigenvalues greater than 1 were kept, as they are the main explanatory factors. Table 6.3 shows the two components: solidarity (warmth, loyalty, temper and sincerity) and status (education, intelligence and elegance). The scores on these two dimensions were then calculated and used in the following regression analyses.

In the following sections, I present results regarding five factors (formality, localness, status, solidarity and occupation suitability). For the first four factors, a series of mixed-effect linear regression models were fitted to the data with each factor's numeric ratings as the dependent variable, the presence/absence of three variables and all possible interactions as fixed predictors, and sentence and listener as the random intercepts. The lmer command in the lme4 package in $\mathrm{R}$ was used (Bates et al., 2015). Model selection was done using the step-down method and by comparing Akaike information criterion (AIC) and Bayesian information criterion (BIC) scores.

\section{Casualness and localness}

First, I present results on the ratings of formality/localness ('Is this utterance more suitable for a dinner conversation or an office meeting?') 
Table 6.4 Results on formality and localness across variables

\begin{tabular}{lll} 
& \multicolumn{2}{l}{ Mean ratings } \\
\cline { 2 - 3 } & Formality & Localness \\
\hline None & 4.04 & 2.48 \\
\hline Neutral tone & 3.94 & 2.71 \\
\hline Intensifier te & 3.50 & 2.85 \\
\hline Classifier omission & 3.63 & 2.52 \\
\hline Neutral tone + Intensifier te & $2.62^{* * *}$ & $3.58^{* * *}$ \\
\hline Neutral tone + Classifier omission & $2.32^{* * *}$ & 2.74 \\
\hline Classifier omission + Intensifier te & $2.81^{* * *}$ & $3.50^{* * *}$ \\
\hline All & $2.58^{* * *}$ & $3.35^{* *}$ \\
\hline
\end{tabular}

Note: ratings range from 1 to $5,5=$ more formal/more local; ${ }^{* *} p<0.01 ;{ }^{* * *} p<0.001$.

and localness ('How likely is it that the speaker is a native Beijinger?'). The best-fit models for both questions contain only the three-way interaction between all Beijing features, suggesting the only significant factor is the different combinations of the features. I include the mean ratings for these two questions across all combinations of the three Beijing features in Table 6.4.

As shown in Table 6.4, a total absence or a very limited use of Beijing features (i.e. the use of one of the three features) is heard as more suitable for a formal setting (all mean values $>3$ ), and the interaction is statistically significant (indicated by asterisks in the table).

Results on perceived localness show a reversed pattern: using all three features (mean $=3.35, p<0.01$ ) and using a combination of two Beijing features are both heard as more local in comparison with not using any Beijing features. Unlike ratings for formality, where the use of any of the three features prompts the same significant decrease in perceived casualness, there is a preferred combination of features in perceived localness. Specifically, the combination of neutral tone and classifier omission is not perceived as significantly local-like (mean $=2.74$, n.s.), whereas the combination of intensifier $t e$ and either neutral tone $($ mean $=3.58)$ or classifier omission $($ mean $=3.50)$ is heard as more local $(p<0.001)$.

\section{Status}

Mixed-effect linear regressions suggest a final model with classifier omission, intensifier te and a two-way interaction between neutral tone and intensifier te. As Table 6.5 shows, using either classifier omission or intensifier te lowers the perceived status score, but the trend is only significant for classifier omission $(p=0.003)$. The interaction between neutral tone and intensifier te was included in the model but was not significant. 
Table 6.5 Output of mixed-effect regression on status

\begin{tabular}{lccccc} 
& Estimate & Std. error & $\boldsymbol{d f}$ & $\boldsymbol{t}$ value & $\boldsymbol{p}$ value \\
\hline (Intercept) & 0.232 & 0.151 & 149.267 & 1.534 & 0.127 \\
\hline Classifier omission (present) & -0.370 & 0.123 & 175.661 & -3.013 & $0.003^{* *}$ \\
\hline Intensifier te (present) & -0.034 & 0.165 & 165.958 & -0.204 & 0.838 \\
\hline Neutral tone (present): Intensifier te (absent) & 0.197 & 0.169 & 172.446 & 1.170 & 0.243 \\
\hline Neutral tone (present): Intensifier te (present) & -0.231 & 0.172 & 173.041 & -1.344 & 0.181 \\
\hline
\end{tabular}

$N=200 ;$ random intercept: listener (50); sentence (2); ${ }^{* *} p<0.01$.

Table 6.6 Output of mixed-effect regression on solidarity

\begin{tabular}{lccccc} 
& Estimate & Std. error & $\boldsymbol{d f}$ & $\boldsymbol{t}$ value & $\boldsymbol{p}$ value \\
\hline (Intercept) & -0.186 & 0.143 & 150.814 & -1.304 & 0.194 \\
\hline Neutral tone (present) & 0.304 & 0.188 & 184.742 & 1.612 & 0.109 \\
\hline Intensifier te (present) & 0.276 & 0.187 & 176.114 & 1.476 & 0.142 \\
\hline $\begin{array}{l}\text { Neutral tone (present): } \\
\text { Intensifier te (present) }\end{array}$ & -0.388 & 0.265 & 177.219 & -1.466 & 0.144 \\
\hline
\end{tabular}

$N=200 ;$ random intercept: listener (50); sentence (2).

\section{Solidarity}

The results for ratings on the solidarity dimension show a similar lack of significance (Table 6.6). Neutral tone and intensifier te, together with their interaction, were selected for the final model. Although the use of either or both features tends to increase solidarity ratings, none of these tendencies was significant. Classifier omission was not included in the final model.

\section{Occupation suitability}

Since occupation suitability ratings are neither numeric nor strictly ordinal, I treat them as categorical in this analysis. In Figure 6.1, I present the percentage of different occupations chosen for each Beijing Mandarin feature combination by the listeners. Listeners chose 'assistant' as a suitable occupation for most of the stimuli, and there seems to be a trend for speakers to be assigned lower occupations (e.g. taxi driver) when using more Beijing features.

\section{Discussion}

In this section, I discuss the results from the experiment, focusing on the social meaning of neutral tone variation. Following the order of the 


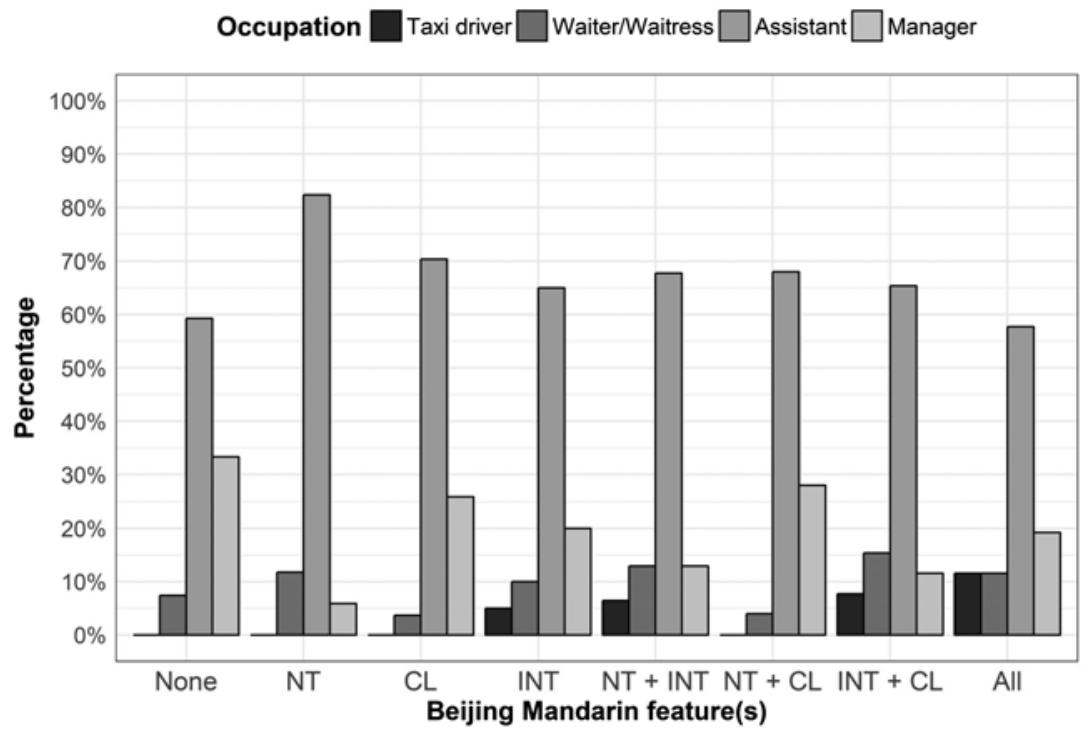

Figure 6.1 Occupation suitability ratings across Beijing features NT: neutral tone; CL: classifier omission; INT: intensifier te.

Results section above, meanings related to casualness and localness will be discussed first and then those regarding status, solidarity and occupation suitability.

\section{Casualness and localness}

Results from the statistical analyses have shown that the three Beijing features share some social meanings in perception. They are all associated with both casualness and localness, although the relationship is not merely a simple and direct correlation. As we find no main effect for any of the three features and instead observe a complex and significant threeway interaction, the meanings of casualness and localness are only present in perception when multiple features are involved.

To illustrate, the use of two or more Beijing features, regardless of which of the three, is heard as more suitable for a more casual setting, in this case, a dinner conversation among familiar interlocutors. Using only one of the three features is not perceived as more casual than an absence of Beijing features.

Regarding localness, the results reveal that more than one Beijing feature must be used for listeners to hear this as more local. The use of any individual feature is not associated with localness. It is worth noting that for localness, different combinations of features differ in the meanings they evoke in perception: Using neutral tone and classifier omission 
together does not seem to be heard as more local, whereas combinations involving intensifier te are perceived as local. As the use of $t e$ is often documented as a regional feature, whereas neither neutral tone (which is used in many varieties) or classifier omission (ungrammatical in other varieties) is purely regional, it is unsurprising to see te and combinations involving it being perceived as local. Another possible contributor to this correlation is the lexical nature of intensifier te: in comparison to the other two variables (phonetic and grammatical), it is potentially easier for participants to recognize lexical item such as intensifiers in perception.

The findings first suggest that Beijing features share common meanings such as casualness and localness, which are often related to vernacular varieties (Labov, 1963, 2002). As part of the local vernacular in Beijing, it is unsurprising that these linguistic features are heard as less suitable for formal settings and as more local, but this study is the first perception study to support the existence of these social meanings previously suggested by research on Beijing Mandarin in general and on specific features including the three examined here (Dong, 2004; Du, 1993; Hao, 2012; Qi, 2012; Zhang, 2005).

Furthermore, the study reveals that these meanings are perceived by the listeners when the three features combine with each other, rather than when they are used in isolation. While previous perceptual studies on linguistic variation suggest that meanings can be and are usually carried by individual features alone (cf. Campbell-Kibler, 2009; Drager, 2010; Levon \& Fox, 2014), in fact, these two types of findings are not contradictory. The methodologies of previous studies investigating how meanings are perceived in the variation of individual linguistic features (e.g. CampbellKibler, 2006; Walker et al., 2014b) were not designed to find interactions between features in perception. However, as shown in Levon's (2006) study on different prosodic features in English, linguistic features often interact in the process of meaning-making. The current study further confirms that finding. This is not to say that the three features do not convey these meanings individually, as existing research has suggested that neutral tone is perceived as less standard and prestigious in perception and is used to convey casualness and localness in production (Zhao, 2018a, 2018b). Rather, the findings here complement previous findings on the meanings of neutral tone. Regarding the meanings of the other two features, as well as of many other Beijing Mandarin features, more research is needed.

\section{Status, solidarity and occupation suitability}

Although the three Beijing features share meanings including casualness and, to a lesser extent, localness, their associations with meanings related to status and solidarity vary. The only significant relationship is between classifier omission and the perceived talker status: omitting 
classifiers leads to the talker being perceived as lower on the status dimension. Since classifier omission is ungrammatical in standard Chinese (Huang et al., 2009), whereas the use of neutral tone and intensifier te is merely seen as dialectal, the negative correlation of classifier omission with status is unsurprising. Even though the use is acceptable in the Beijing variety (both according to grammars and speakers), lay listeners still assign a low status to the ungrammatical use of classifiers (according to prescriptive rules in the standard language) but rate the other two dialectal features as high-status, possibly because they do not violate any grammatical rules. As mentioned, a command of the standard use of the official language is often linked by speakers with a high education level and social status.

The study produced no significant results on questions regarding solidarity. This is inconsistent with previous studies, where a high level of solidarity is usually shared by dialect and non-standard language users (Callan \& Gallois, 1982, 1987; Feifel, 1994); however, a similar lack of significant results has been seen in Chinese languages including Beijing Mandarin, Penglai Mandarin, Singaporean Mandarin and Taiwan Mandarin (Chong \& Tan, 2013; Zhang, 1990). There are two possible explanations: First, since all stimuli contain very slight changes and are relatively similar, listeners could have perceived them as very similar and thus rated them similarly. This is less likely to be the case, as listeners were able to rate the casualness and localness of the same stimuli. The second explanation points to the effect of the vigorous Putonghua promotion in China, where Chinese speakers, regardless of their own language backgrounds, identify with the standard variety as much as with their local varieties, as suggested by Zhang (1990), but further studies are needed to verify this explanation.

Despite a trend where the presence of Beijing features reduces the probability of the talker being perceived as having a high-level job, the use of these features seems to make little significant difference in how talkers are perceived. Together with the non-significant results from the status (apart from classifier omission) and solidarity dimensions, this is further evidence that Beijing Mandarin is not perceived in the same way as typical low-prestige vernaculars (Campbell-Kibler, 2006; Chong \& Tan, 2013; Feifel, 1994; Holmes, 2013; Lin, 1987; Zhang, 1990). Using Beijing features is not seen as overtly low-status, high-solidarity and only suitable for low-level occupations, although the variety is still perceived as casual and local. This might suggest that Beijing Mandarin, as a vernacular of the capital city, lacks the negative low-prestige meanings traditionally associated with non-standard vernaculars. Instead, it enjoys a certain prestige and may even be in competition with the standard variety. However, there is as yet no empirical evidence for this, so more relevant work is needed. This prestige, in turn, perhaps gives speakers the chance to use the local variety without being penalized in identity-building. 
Q. Zhang's work on Beijing business professionals $(2005,2008)$ shows, for example, that high-ranking state professionals employ Beijing vernacular features without being negatively perceived.

\section{Conclusion}

Based on the results of a matched-guise test on the perception of three Beijing Mandarin features - neutral tone, classifier omission and intensifier $t e$ - this study has examined the social meaning associated with these features. Firstly, as part of the local vernacular, the three Beijing Mandarin features convey meanings related to casualness and localness. This is consistent with existing research on vernacular varieties in and outside of China. Secondly, apart from the ungrammatical use of classifier omission, the use of Beijing features has little influence on ratings regarding status, solidarity or occupation suitability. This might be explained by the lack of prescriptive differences between the Beijing and the standard varieties (for status and occupation suitability), together with the effects of longterm standard language promotion (for solidarity). These two main findings demonstrate that although Beijing features are local and casual, they do not differ from the standard language in the other aspects. This lack of distinction in perception between the 'non-standard' and the 'standard' Chinese challenges the traditional theorization of standard languages that heavily relies on written forms and language production and calls for more attention to language perception in sociolinguistic research related to (non-)standardness. A lack of contrast in prestige between the dialect and standard language could also lead to language variation and change on a larger scale, but further studies are needed for a more conclusive answer. Apart from these key findings, it is also noteworthy that the Beijing features convey their meanings as a unit rather than independently in perception. While this could be due to the method used here, it is in line with other findings about interactions between features, and it enriches our understanding of how language variation is perceived.

The results here are only partly consistent with the existing literature, though the inconsistent results could be explained by the unique linguistic and social contexts in China. To further advance our understanding of the perceived relationships between standard and local varieties, and to explore to what extent Beijing Mandarin may be a special case, future research will need to investigate other variables in Beijing Mandarin, as well as in other regional varieties in China. It may be that Beijing Mandarin is not negatively perceived because of its prestige. It would be interesting to explore to what extent other prestigious varieties (e.g. Cantonese) are in competition with the standard language as well. Understanding such potential competition is important both for language variation studies and language policy and planning in China, as positive social meanings can drive language change. 


\section{Acknowledgements}

I would like to thank Prof Devyani Sharma, Prof Erez Levon and Prof Nicola McLelland for their help in this project and in this chapter. I also thank the anonymous reviewers for their comments on previous drafts. This work was supported by the Economic and Social Research Council [grant number 1368069] and by the Arts and Humanities Research Council [grant number AH/N004671/1].

\section{Note}

(1) Non-migrant residents are defined as those who have permanent residency in Beijing and have lived there for more than six months (i.e. excluding internal and foreign migrants), although it is unlikely all of them speak Beijing Mandarin.

\section{References}

Abbuhl, R., Gass, S. and Mackey, A. (2014) Experimental research design. In R.J. Podesva and D. Sharma (eds) Research Methods in Linguistics (pp. 116-134). Cambridge: Cambridge University Press.

Babcock, R.D. (2014) Folk-linguistic attitudes in eastern Massachusetts. Open Journal of Modern Linguistics 4, 415-428.

Bates, D., Machler, M., Bolker, B. and Walker, S. (2015) Fitting linear mixed-effects models using lme4. Journal of Statistical Software 67 (1), 1-48.

Becker, M. and Levine, J. (2014) Experigen - An online experiment platform. See http:// becker.phonologist.org/experigen (accessed 11 July 2021).

Beijing Municipal Bureau of Statistics (BMBS) (2020) 北京统计年鉴 2020 [Beijing Statistical Yearbook 2020]. Beijing: China Statistics Press.

Benor, S.B. (2001) The learned/t/: Phonological variation in Orthodox Jewish English. Penn Working Papers in Linguistics: Selected Papers from NWAV 2000, 1-16.

Benson, E.J. (2003) Folk linguistic perceptions and the mapping of dialect boundaries. American Speech 78 (3), 307-330.

Bucholtz, M. (2001) The whiteness of nerds: Superstandard English and racial markedness. Journal of Linguistic Anthropology 11 (1), 84-100.

Bucholtz, M. and Hall, K. (2005) Identity and interaction: A sociocultural linguistic approach. Discourse Studies 7 (4-5), 585-614.

Callan, V.J. and Gallois, C. (1982) Language attitudes of Italo-Australian and GreekAustralian bilinguals. International Journal of Psychology 17 (1-4), 345-358.

Callan, V.J. and Gallois, C. (1987) Anglo-Australians' and immigrants' attitudes toward language and accent: A review of experimental and survey research. International Migration Review 21 (1), 48-69.

Campbell-Kibler, K. (2006) Listener perceptions of sociolinguistic variables: The case of (ING). PhD thesis, Stanford University.

Campbell-Kibler, K. (2009) The nature of sociolinguistic perception. Language Variation and Change $21(1), 135-156$.

Campbell-Kibler, K. (2011) Intersecting variables and perceived sexual orientation in men. American Speech 86 (1), 52-68.

Chao, Y.R. (1968) A Grammar of Spoken Chinese. Berkeley: University of California Press.

Chen, Y. and Xu, Y. (2006) Production of weak elements in speech - Evidence from F0 patterns of neutral tone in standard Chinese. Phonetica 63 (1), 47-75.

Chong, R.H.-H. and Tan, Y.-Y. (2013) Attitudes toward accents of Mandarin in Singapore. Chinese Language and Discourse 4 (1), 120-140. 
Dong, X. (2004) 北京话名词短语前阳平“一”的语法化倾向 [The grammaticalisation of second-tone 'yi' followed by noun phrases in Beijing Mandarin]. In F. Wu and B. Hong (eds) 语法化与语法研究 [Grammaticalization and Grammar Research] (pp. 167-170). Beijing: Commercial Press.

Drager, K. (2010) Sociophonetic variation in speech perception. Language and Linguistics Compass 4 (7), 473-480.

Du, Y. (1993) 北京话中的“一+名” [“yi +ming' in Beijing Mandarin]. 中国语文 [Studies of the Chinese Language] 2, 142.

Eckert, P. (1988) Adolescent social structure and the spread of linguistic change. Language in Society 17 (2), 183-207.

Eckert, P. (2008) Variation and the indexical field. Journal of Sociolinguistics 12 (4), $453-476$.

Eckert, P. (2012) Three waves of variation study: The emergence of meaning in the study of sociolinguistic variation. Annual Review of Anthropology 41, 87-100.

Feifel, K.-E. (1994) Language Attitudes in Taiwan: A Social Evaluation of Language in Social Change. Taipei: Crane Publishing Company.

Fu, Q. (2014) 北方三地方言中程度副词比较 [Comparison of the adverbs of degree of dialect of three regions in Northern China]. 天津职业院校联合学报 [Journal of Tianjin Vocational Institutes] 16 (7), 51-55.

Hao, J. (2012) 浅谈北京话口语中的单音节程度副词 [A brief discussion on monosyllabic degree adverbs in Beijing Mandarin]. 现代汉语 [Modern Chinese] 6, 22-24.

Holmes, J. (2013) An Introduction to Sociolinguistics. Harlow: Pearson.

$\mathrm{Hu}$, M. (1986a) 普通话和北京话 (上) [Putonghua and Beijing Mandarin I]. 语文建设 [Language Planning] 3, 47-50.

Hu, M. (1986b) 普通话和北京话 (下) [Putonghua and Beijing Mandarin II]. 语文建设 [Language Planning] 4, 49-51.

Hu, M. (1987) 北京话初探 [A Preliminary Study of the Dialect of Beijing]. Beijing: Commercial Press.

Huang, C.T.J., Li, Y.H.A. and Li, Y. (2009) The Syntax of Chinese. Cambridge: Cambridge University Press.

Huang, J. (2003) 省略一和省略量词 [On omitting 'yi' and omitting classifiers]. 青海教育 [Qinghai Education] 11, 22.

Jing, S. (2002) 现代汉语轻声动态研究 [A Dynamic study on Neutral Tone in Modern Chinese]. Beijing: Ethnic Publishing House.

Jing, S. and Zhu, Y. (2016) Attitude, maintenance, and use of Beijing dialect and Putonghua among younger generation Beijing-born residents. Journal of Asian Pacific Communication 26 (1), 32-55.

Johnstone, B. and Kiesling, S.F. (2008) Indexicality and experience: Exploring the meanings of /aw/-monophthongization in Pittsburgh. Journal of Sociolinguistics 12 (1), $5-33$.

Labov, W. (1963) The social motivation of a sound change. Word 19 (3), 273-309.

Labov, W. (1966) The Social Stratification of English in New York City. Washington: Center for Applied Linguistics.

Labov, W. (1972) Sociolinguistic Patterns. Philadelphia, PA: University of Pennsylvania Press.

Labov, W. (2002) The anatomy of style-shifting. In P. Eckert and J.R. Rickford (eds) Style and Sociolinguistic Variation (pp. 85-108). Cambridge: Cambridge University Press.

Lai, M.L. (2007) Exploring language stereotypes in post-colonial Hong Kong through the matched-guise test. Journal of Asian Pacific Communication 17 (2), 225-244.

Lambert, W.E., Frankle, H. and Tucker, G.R. (1966) Judging personality through speech: A French-Canadian example. Journal of Communication 16 (4), 305-321.

Levon, E. (2006) Hearing "gay": Prosody, interpretation, and the affective judgments of men's speech. American Speech 81 (1), 56-78.

Levon, E. and Fox, S. (2014) Social salience and the sociolinguistic monitor: A case study of ING and TH-fronting in Britain. Journal of English Linguistics 42 (3), 185-217. 
Li, C.N. and Thompson, S.A. (1981) Mandarin Chinese: A Functional Reference Grammar. Berkeley: University of California Press.

Lin, T. (2000) 普通话和北京话 [Putonghua and Beijing Mandarin]. Beijing: Language and Culture Press.

Lin, Y.-C. (1987) The social evaluation of Mandarin and Taiwainese in Taipei: A case study of attitudes towards language variation and language use. Master's thesis, National Taiwan Normal University.

Lin, Y., Li, J. and Qiu, J. (2010) 瑶族儿童对普通话、方言和民族语的印象: 一个匹配伪装 实验 [Yao children's language impression on Mandarin, dialect and their own language: A matched-guise experiment]. 广西师范大学学报 (哲学社科版) [Journal of Guangxi Normal University (Philosophy and Social Sciences Edition)] 46 (4), 6-11.

Liu, D. and Cao, W. (2011) 北京话“特”类情状方式副词的历史嬗变 [The diachronic evolution of the degree adverbs 'te' in Beijing Vernacular]. 北京理工大学学报 (社科版) [Journal of Beijing Institute of Technology (Social Sciences Edition)] 13 (5), 137-141.

Liu, X. (2004) 北京话”一+名”结构分析 [A structural analysis of 'yi + ming' in Beijing Mandarin]. 中国语文 [Studies of the Chinese Language] 1, 36-39.

Lu, Y. (1995) 普通话的轻声和儿化 [Neutral Tone and Rhotacisation in Putonghua]. Beijing: Commercial Press.

Milroy, J. and Milroy, L. (1978) Belfast: Change and variation in an urban vernacular. In P. Trudgill (ed.) Sociolinguistic Patterns in British English (pp. 19-36). London: Arnold.

Moore, E. and Podesva, R.J. (2009) Style, indexicality, and the social meaning of tag questions. Language in Society 38 (4), 447-485.

Norman, J. (1988) Chinese. Cambridge: Cambridge University Press.

Pharao, N., Maegaard, M., Møller, J.S. and Kristiansen, T. (2014) Indexical meanings of $[\mathrm{s}+]$ among Copenhagen youth: Social perception of a phonetic variant in different prosodic contexts. Language in Society 43 (01), 1-31.

Podesva, R.J. and Chun, E. (2007) On indeterminacy in the social meaning of variation. Paper presented at the New Ways of Analyzing Variation (NWAV) 36, 11-14 October 2007, Philadelphia.

Podesva, R.J., Roberts, S.J. and Campbell-Kibler, K. (2002) Sharing resources and indexing meanings in the production of gay styles. In K. Campbell-Kibler, R.J. Podesva, S.J. Roberts and A. Wong (eds) Language and Sexuality: Contesting Meaning in Theory and Practice (pp. 175-189). Chicago: University of Chicago Press.

Preston, D.R. (2011) Methods in (applied) folk linguistics: Getting into the minds of the folk. AILA Review 24 (1), 15-39.

Qi, S. (2012) 现代汉语程度副词与形容词的搭配选择关系 [Selective correlations in combining degree adverbs and adjectives in Modern Mandarin Chinese], Master's thesis, Peking University.

R Core Team (2020) R: A Language and Environment for Statistical Computing. Vienna: $R$ Foundation for Statistical Computing.

Silverstein, M. (1976) Shifters, linguistic categories and cultural description. In K.H. Basso and H.A. Selby (eds) Meaning in Anthropology (pp. 11-55). Santa Fe, NM: University of New Mexico Press.

Street, R.L.J. and Brady, R.M. (1982) Speech rate acceptance ranges as a function of evaluative domain, listener speech rate, and communication context. Communications Monographs 49 (4), 290-308.

Street, R.L.J., Brady, R.M. and Putman, W.B. (1983) The influence of speech rate stereotypes and rate similarity or listeners' evaluations of speakers. Journal of Language and Social Psychology 2 (1), 37-56.

Tamminga, M. (2017) Matched guise effects can be robust to speech style. The Journal of the Acoustical Society of America 142 (1), EL18-EL23. 
Tao, L. (2006) Classifier loss and frozen tone in spoken Beijing Mandarin: The yi+ge phono-syntactic conspiracy. Linguistics 44 (1), 91-133.

Trudgill, P. (1974) The Social Differentiation of English in Norwich. Cambridge: Cambridge University Press.

Villarreal, D. (2018) The construction of social meaning: A matched-guise investigation of the California Vowel Shift. Journal of English Linguistics 46 (1), 52-78.

Walker, A., García, C., Cortés, Y. and Campbell-Kibler, K. (2014a) Comparing social meanings across listener and speaker groups: The indexical field of Spanish/s. Language Variation and Change 26 (02), 169-189.

Walker, A., García, C., Cortés, Y. and Campbell-Kibler, K. (2014b) Comparing social meanings across listener and speaker groups: The indexical field of Spanish/s/. Language Variation and Change 26 (2), 169-189.

Wolfram, W. (1969) A Sociolinguistic Description of Detroit Negro Speech. Washington: Center for Applied Linguistics.

Wu, Y. (2005) 北京话“一个”弱化的原因 [Cause of neutralisation of 'yige' in Beijing Mandarin]. 语言教学与研究 [Language Teaching and Linguistic Studies] 2, 63-67.

Xu, S. (1990) 北京土语词典 [Dictionary of Vernacular Beijing Dialect]. Beijing: Beijing Publishing Group.

Zhang, J. (1990) 教师口音的社会心理影响 [Socio-psychological influence of teachers' accents]. 心理科学 [Psychological Science] 6, 50-53.

Zhang, J., Yang, Z. and Zhu, S. (2003) 广东大学生对普通话和粤语的印象 [Study into the impressions of Putonghua and Guangdong dialect in Guangdong university students' eyes]. 心理学探新 [Exploration of Psychology] 1, 51-54.

Zhang, Q. (2001) Changing economy, changing market: A sociolinguistic study of Chinese yuppies. PhD thesis, Stanford University.

Zhang, Q. (2005) A Chinese yuppie in Beijing: Phonological variation and the construction of a new professional identity. Language in Society 34 (3), 431-466.

Zhang, Q. (2007) Cosmopolitanism and linguistic capital in China: Language, gender and the transition to a globalized market economy in Beijing. In B.S. McElhinny (ed.) Words, Worlds, and Material Girls: Language, Gender, Globalization (pp. 403-422). Berlin: Mouton de Gruyter.

Zhang, Q. (2008) Rhotacization and the 'Beijing Smooth Operator': The social meaning of a linguistic variable. Journal of Sociolinguistics 12 (2), 201-222.

Zhao, H. (2018a) Language variation and social identity in Beijing. PhD thesis, Queen Mary University of London.

Zhao, H. (2018b) Social meaning in the perception of neutral tone variation in Putonghua. Asia-Pacific Language Variation 4 (2), 161-196.

Zhou, C. (2006) 北京话轻声、儿化、轻入字的变异研究 [A study on the variation in Neutral Tone, Erhua and Qingruzi in Beijing Mandarin]. PhD thesis, Beijing Language and Culture University.

Zhou, Y. (1998) 北京口语语法: 词法卷 [A Grammar of Spoken Beijing Mandarin: Lexicology]. Beijing: Language and Culture Press.

Zhou, Y. (2002) 现代北京话研究 [Research on Modern Beijing Mandarin]. Beijing: Beijing Normal University Press.

\section{Appendix}

1 Based on the speaker's style of speaking, NOT the content, he/she is: [on a scale from 1 to 5]

Talking to parents/friends at dinner table - reporting to work supervisors at a meeting 
2 The speaker sounds: [on a scale from 1 to 5]

2.1 Elegant - Vulgar

2.2 Ill-tempered - Nice

2.3 Not educated - Well-educated

2.4 Sincere - Hypocritical

2.5 Very intelligent - Not intelligent

2.6 Not loyal - Loyal

2.7 Friendly - Unfriendly

2.8 Like a subordinate - Like a leader

3 Does the speaker sound like a Beijinger? [on a scale from 1 to 5]

4 Which one of the following occupations is most possible for this speaker? (choose from below)

Manager at a famous international business; office assistant in a wellknown Chinese (national) company; local restaurant waiter/waitress; taxi driver in Beijing. 